\title{
Discurso militar e identidad nacional chilena
}

\author{
Hernán Cuevas Valenzuela \\ Facultad de Ciencias Sociales e Historia, Universidad Diego Portales, \\ Santiago de Chile. \\ E-mail: hernan.cuevas.icso@gmail.com
}

\begin{abstract}
Resumen: Este artículo estudia el discurso militar sobre la identidad nacional chilena. Se plantea que la identidad nacional resulta de un proceso permanente y abierto de formación que no es evidente en todas sus aristas. Por ello, el estudio de la identidad no sólo requiere revelar sus prácticas y contenidos discursivos manifiestos, sino que también debe examinar sus contenidos latentes para identificar los variados mecanismos que confluyen en su formación. Para lograrlo se propone la complementariedad del análisis cualitativo de contenido, el análisis estructural del discurso y el análisis de la morfología del discurso. La conclusión plantea que a pesar de importantes cambios, el discurso militar sobre la identidad nacional ha mantenido su rasgo conservador basado en una ontología social esencialista. Chile.

Palabras clave: Análisis de discurso, discurso militar, identidad nacional,
\end{abstract}

\section{Military speech and chilean national identity}

\begin{abstract}
This article studies the military discourse on chilean national identity. The article states that national identity is a permanent and open-ended process of social construction that is not evident in all its aspects. For this reason, the study of identity requires not only to reveal discourse's practices and manifest contents, but it must also examine its latent content to identify the various mechanisms that come together in its production. For this, it proposes the complementarity of qualitative content analysis, structural analysis of discourse and analysis of the morphology of discourse. The conclusion is that despite important changes, the military discourse on national identity has maintained its conservative trait based on an essentialist social ontology.
\end{abstract}

Key words: Speech analysis, military speech, national identity, Chile.

\section{Discurso militar e identidade nacional chilena}

Resumo: Este artigo estuda o discurso militar sobre a identidade nacional chilena. Ele argumenta que a identidade nacional é o resultado de um processo contínuo e aberto de formação que não é evidente em todas suas bordas. Portanto, o estudo da identidade requer não só revelar suas práticas e o conteúdo discursivo manifesto, mas também deve examinar o seu conteúdo latente para identificar os vários mecanismos que moldam sua formação. Para alcançar este objetivo, propõese a complementaridade da análise qualitativa de conteúdo, a análise estrutural do discurso e a análise da morfologia do discurso. A conclusão sugere que, apesar das significativas mudanças, o discurso militar sobre a identidade nacional tem mantido um traço conservador baseado numa ontologia social essencialista. 
Chile.

Palavras-chave: Análise de discurso, discurso militar, identidade nacional,

$* * *$

\section{Introducción}

Este artículo estudia el discurso del Ejército de Chile acerca de la identidad nacional (de ahora en adelante IN) y explora sus continuidades y discontinuidades en dos períodos: el gobierno dictatorial del General Augusto Pinochet ${ }^{1} \mathrm{y}$ el período que se inicia con la comandancia en jefe del General Juan Emilio Cheyre. ${ }^{2}$ Entre ambos hay una separación de varios lustros caracterizados por profundos y dinámicos cambios: golpe militar y quiebre de la antigua democracia chilena, transición, instauración de las nuevas instituciones y consolidación de la nueva democracia. Es importante mencionar estos diferentes contextos históricos por dos razones. Primero, mientras los generales Cheyre e Izurieta expresan las opiniones del alto mando del Ejército en democracia y sometidos a la autoridad civil, la posición de enunciación del General Augusto Pinochet coincide con la del mandatario-dictador. Segundo, los desafíos discursivos a los que se enfrenta uno y otro son diferentes, pues se derivan de los momentos históricos distintos. El General Pinochet se había planteado una profunda reestructuración económica y social, una reforma política e institucional de proporciones, y un cambio cultural que definía como un reencuentro con los valores y tradiciones patrios. En cambio, el proceso iniciado con el General Juan Emilio Cheyre tiene propósitos casi exclusivamente militares o internos asociados a la modernización de la institución y sus funciones. La única excepción a esta norma fue el propósito de restablecer las confianzas entre civiles y militares por medio del reconocimiento público de las responsabilidades del Ejército en las violaciones a los derechos humanos llevadas adelante por aparatos del Estado durante el régimen militar.

Mi conjetura inicial era que el discurso militar (de ahora en adelante DM) acerca de la IN había sufrido cambios de enormes proporciones en este período de más de tres décadas. La primera discontinuidad que salta a la vista se refiere a los diferentes "otros" amenazantes y los riesgos ante los que se define la IN chilena. Mientras en el período de Pinochet las ideologías foráneas, la cultura extranjera, la politización y el antagonismo de clases son los elementos que amagan la IN y sus valores esenciales, en el período de inaugurado con el General Cheyre son el riesgo de la pérdida o debilitamiento de dichos valores que aseguran la cohesión social, en parte producto del inevitable proceso de globalización. Otra discontinuidad importante es la emergencia de nuevos temas para la función de defensa y seguridad, entre los que destaca la consideración de un conjunto de amenazas emergentes. Estas no parecen amenazar la integridad de la identidad nacional, aunque sí el buen funcionamiento de la sociedad y su cohesión. Asociado al punto anterior, se observa que emerge una visión más integral de la seguridad que incluye: la consideración de la salud y seguridad de la 
población en casos de desastres naturales y situaciones de riesgo; la contribución al desarrollo integral de la nación en tiempos de paz; la integración y cooperación regional; la ejecución de acciones de paz a nivel internacional; además de la tradicional defensa territorial. Finalmente, en este período se expresa un compromiso histórico con el respeto y promoción de los derechos humanos y la democracia.

A pesar de los muy distintos contextos históricos de las diferentes Jefaturas del Ejército estudiadas, también existen continuidades discursivas importantes. En el centro de estas continuidades discursivas destacan la noción esencialista de la IN chilena, la misión del Ejército de garante y defensor de los valores patrios, y la unidad orgánica del Ejército y el pueblo de Chile. También en ambos momentos identifiqué una narrativa compartida acerca del paralelismo histórico del Estado chileno y el Ejército. Además observé un conjunto de significantes adyacentes que también presentan continuidad: la bravura y el temple del ejército y el pueblo chileno que nunca se han rendido, sus aptitudes cívicas y democráticas, la estabilidad de sus instituciones y la singularidad republicana de Chile.

La IN es una formación contingente resultante de un continuo y abierto proceso discursivo. ${ }^{3}$ Una de las críticas más frecuentes a este tipo de aproximaciones constructivistas es que desestiman la estabilidad de lo social y el rol de la estructura. Sin embargo, es un error pensar que toda posición constructivista está impedida de pensar la estructuración de la formación de identidad. Como se verá, el proceso de identificación, la estructura de fantasía y la hegemonización del campo discursivo - es decir, los efectos del poder- otorgan efectividad y estabilidad al discurso.

Por discurso entiendo un conjunto de secuencias significativas interrelacionadas que constituyen un sistema más o menos abierto. Los límites del discurso son difusos y dependen no sólo de sus elementos internos sino además de su definición de una exterioridad constitutiva. Así, el DM sobre la IN no sólo está constituido por una serie de contenidos positivos específicos sobre Chile y la chilenidad, sino que también por un antagonismo de carácter ontológico.

El DM sobre la IN entrelaza a la nación y al Ejército, proveyendo a este último de un horizonte de interpretación y una auto-comprensión que vincula la tradición propia con la historia nacional. Por otra parte, el discurso sobre IN requiere para su reproducción del actor Ejército que lo utiliza y que lo varía iterativamente. Cada despliegue lo reproduce y modifica. En consecuencia, existe una relación dialéctica entre la constitución discursiva de la identidad del agente y la reproducción del discurso por parte del agente productor.

El material analizado corresponde a los discursos de las máximas autoridades del Ejército. Dadas sus características de jerarquía y obediencia, puede sostenerse que estos son representativos de la institución. Los discursos de los generales Pinochet, Cheyre e Izurieta fueron escogidos 
por criterios de relevancia, carácter fundacional o por ser altamente simbólicos.

En las secciones 2, 3 y 4 analizo sucesivamente los contenidos del DM sobre la IN chilena usando primero un variante de análisis cualitativo de contenido (Coffey y Atkinson 1996), luego aplicando el análisis estructural del discurso (de ahora en adelante AED) (Martinic 1992; 2006) y, finalmente, el análisis de la morfología del discurso (Feeden 1996). Con ello, mi propósito es demostrar la complementariedad de estas operaciones analíticas. Sustentado en los análisis previos, en las secciones 5 a 9 se plantea que la IN no es dada sino que es un proceso permanente y abierto de formación que no es evidente en todas sus aristas. Por ello, el estudio de la identidad no sólo requiere revelar sus prácticas y contenidos discursivonarrativos manifiestos, sino que también se examinan sus contenidos latentes. Se analizan algunos mecanismos de formación de identidad como son la identificación/desidentificación, la proyección, la construcción de un 'nosotros' vs. unos 'otros', la construcción de fronteras que más que físicas son culturales y políticas, y la producción de narrativas y mitos nacionales sustentados en una estructura que involucra traumas y fantasías colectivas que pueden operar en el nivel subconsciente. La conclusión plantea que a pesar de importantes cambios, el DM sobre la IN ha mantenido su rasgo conservador basado en una ontología social esencialista.

\section{El discurso del ejército sobre la identidad nacional}

En esta sección presento brevemente algunos de los resultados producidos por medio de un proceso inductivo de codificación libre de material textual (Coffey y Atkinson 1996). Este tipo de análisis -inspirado en los procedimientos descritos por la Grounded Theory- es el primer procedimiento que frecuentemente siguen los analistas de habla y texto. ${ }^{4}$ Aunque básico, la aplicación de este procedimiento nos proveerá de un primer acercamiento analítico a los temas que estructuran los discursos de los Comandantes en Jefe del Ejército de Chile. Sobre la base de esos temas identifiqué la representación de la IN en el DM en sus líneas más gruesas.

Una de las representaciones de la nación chilena que más llama la atención en el discurso del Ejército de Chile es la de una cierta raza chilena. En diferentes ocasiones el General Pinochet se refiere al pueblo de Chile literalmente usando el término "raza”. También se refiere al pueblo como “mestizo” y/o “homogéneo” (Pinochet 1974; 1981). Esta visión naturaliza la IN y la ancla en la biología. Esta visión no desaparece del todo en el DM y, como veremos, está presente también en las representaciones de períodos más recientes. Volveremos a este punto más adelante.

Por el momento quisiera concentrarme en la representación de varias figuras referidas al amor patrio -una de las formas concretas de expresión del código Patria- que es característico del pueblo de Chile (y que por extensión, es presentado como característico de la raza chilena). En el dis- 
curso de Chacarillas, el General Pinochet (1977) comparó el sacrificio y devoción por la patria de los 77 soldados muertos en la Batalla de la Concepción con la “liberación” del 11 de Septiembre de 1973. El párrafo a continuación no es accidental, sino que ejemplifica una comprensión típica que es descriptiva del tono general del DM. ${ }^{5}$

1 Hace muy poco, de nuevo el pueblo chileno supo reeditar durante tres años de heroica

2 lucha en contra de la inminente amenaza de totalitarismo comunista, aquel supremo

3 grito de guerra de la Batalla de la Concepción: "Los chilenos no se rinden jamás". Y

4 cuando acudiendo al llamado angustioso de nuestra ciudadania, las Fuerzas Armadas y

5 de Orden, decidieron actuar el 11 de septiembre de 1973, nuevamente nuestra tierra fue

6 regada por la sangre de muchos de nuestros hombres, que cayeron luchando por la

7 liberación de Chile. Quedaba de este modo en evidencia que el temple de nuestra raza

8 y la fibra de nuestra nacionalidad para defender la dignidad o la soberania de nuestra

9 patria no habian muerto ni podrian morir jamás, porque son valores morales que se

10 anidan en el alma misma de la chilenidad. Hoy, volvemos a enfrentar una lucha

11 desigual, contra una acción foránea de diversos origenes y tonalidades, que a veces

12 adopta la forma de la agresión enemiga, y que en otras ocasiones se presenta bajo el

13 rostro de una presión amiga.

En este significativo párrafo, el General Pinochet destaca una serie de valores y atributos de la "raza" chilena: la valentía, el heroísmo, el amor por la patria, la devoción por la libertad. Es interesante como compara el heroísmo de los soldados chilenos que se inmolaron en La Batalla de la Concepción con la lucha del pueblo chileno "contra la inminente amenaza del totalitarismo comunista" (1-4). De paso, al aludir al "angustioso llamado de nuestra ciudadanía” (4-8) legitima el golpe de estado del 11 de Septiembre de 1973 como un acto de "liberación".

En varias oportunidades el General Pinochet $(1974 ; 1977$; 1981) se refirió al tema de los valores patrios, afincándolos en los "valores superiores del espíritu”, en las propias tradiciones nacionales y en lo que llamó "el alma misma de la chilenidad”. En su perspectiva esencialista, las tradiciones tienen un carácter inconmovible, el que además de primar en cierto conservadurismo intelectual tiene afinidad con el sentido común. Conjuntamente con metáforas biologicistas -como en las alusiones a raza y pueblo chilenos- usó el General Pinochet las nociones de alma y espíritu, que si bien están lejos de los fundamentos biologicistas de la noción de raza, comparten con aquellos la evocación a una identidad profunda, auténtica, esencial.

Entre los valores destacados en el discurso sobresalen la "fe" y “civilización cristina”, aludiendo a una matriz cristiana de la identidad nacional. Pero también se mencionan el respeto a la "autoridad fuerte", "justa" e "impersonal”, con lo cual se afirma el ideario portaliano de autoridad tan presente en la historiografía chilena. ${ }^{6}$ También se destacan como comunes a la nación los valores de "dignidad del hombre”, "patriotismo" y "bravura” del "pueblo", devoción a la "libertad”, "unidad”, "dignidad”, "sobe- 
ranía” y “grandeza”. Este discurso acerca de los valores comunes de la chilenidad representa a la patria unida como "la unidad de la gran familia chilena” (Pinochet, 1974; 1977; 1981). Tanto la figura racial como esta del parentesco filial evocan un linaje común. Son metáforas biológicas y no culturales, se refieren a la naturaleza y no a la construcción social.

Otra característica del discurso es que al favorecer un tipo de autocomprensión, también contribuye a conformar una clase de sujeto: el chileno de verdad. Naturalmente que frente a estos valores del chileno de verdad "transmitidos por cada generación a la siguiente" hay una serie de atributos negativos o desvalores, con lo que implícitamente surge la figura lógicamente concebible de un no-chileno o incluso de un mal chileno (Pinochet 1974; 1977; 1981). Este último es un desarraigado, alguien que traiciona los valores nacionales y, en última instancia, vende a la patria.

El período del General Cheyre tuvo un énfasis diferente, pues se refiere al pueblo chileno reconociendo la "diversidad" del mismo, con lo que observamos una importante discontinuidad respecto del discurso del General Pinochet. Sin embargo, esta discontinuidad, como veremos, no rompe con la matriz conservadora y esencialista del DM.

Parafraseando a San Agustín, el General Cheyre señala que en lo que respecta a la convivencia nacional y la IN se requiere "en lo básico unidad” para en el resto tener la “diversidad”. Expresa que es necesario construir un proyecto que sea reflejo de "un sueño compartido por cuantos nacieron en una misma tierra.” Se trata de un "sueño” que "haga amanecer y terminar el día con felicidad” a las diferentes categorías de personas: “al minero, al profesional, al técnico, al pescador y al ovejero, al civil o militar, al hombre y a la mujer del Norte o del Sur; al joven o al viejo...”. (Cheyre 2003)

Es interesante el carácter onírico de los términos utilizados por el General Cheyre: “sueño”, “amanecer”, “término del día con felicidad” (crepúsculo). Estos representan la idealización positiva del proyecto de unidad. A la vez éste carece de rasgos concretos, lo que es una condición de posibilidad para que mantenga su carácter plenitud y su inclusividad. Por otra parte, los sujetos del sueño constituyen una enumeración de categorías sociolaborales, geográficas, de género y etarias deliberadamente poco conflictivas. No se mencionan clases sociales de intereses antagónicos como obreros y empresarios, ni minorías sexuales invisibilizadas, ni grupos étnicos movilizados políticamente como el pueblo Mapuche. Mientras la unidad nacional es promovida por esta enumeración que sólo en apariencia es todo-inclusiva, el lenguaje onírico también promueve una imaginería y unas emociones que evocan el "sentirnos uno". En el mismo discurso, el General Cheyre (2003) reconoce la existencia de conflictos en la sociedad chilena, pero inmediatamente se plantea esperanzado en lograr la "común unidad tras un proyecto que nos dé certeza de futuro y nos asegure solución gradual de las asimetrías y sobre todo no sea excluyente de nadie.” Este tipo de reconocimiento de heterogeneidad tiene dos fuertes restricciones. Primero, la diferencia desaparece ante lo básico e importante (cita de 
San Agustín). Como consecuencia lógica de la jerarquía que el discurso otorga al principio de unidad la diferencia debe asimilarse o subordinarse al proyecto de unidad de la mayoría o de los que tienen capacidad de interpelar a la población. Segundo, por medio de la idea del trato igualitario a los individuos promueve un universalismo nacional-ciudadano que esconde las diferentes posiciones de sujeto: subculturas, pueblos originarios, grupos oprimidos, grupos de personas con habilidades diferenciadas, etc. El proyecto común, el "sueño" compartido del General Cheyre, es un significante ideológico en el sentido que representa ficticiamente un espacio de universalidad no excluyente, pero que desde una lectura crítica y desmitificadora, se revela como excluyente. Este es un discurso que articula elementos conservadores y liberales, pues trata la diversidad como un objeto de asimilación en la tradición cultural mayoritaria y como una realidad posible de ser domesticada por la categoría universal de ciudadano del estado nacional.

Por su parte, en su discurso con ocasión del Juramento a la Bandera el General Óscar Izurieta (2007) rememora celebratoriamente el sacrificio de los 77 jóvenes soldados chilenos en la Batalla de la Concepción y se refiere al pueblo de Chile como una unidad racial homogénea, en continuidad con las expresiones del General Pinochet.

... junto con representar el más legítimo orgullo para quienes vestimos su uniforme, constituye también un patrimonio de la raza, que cada chileno lleva con unción en lo más profundo de su corazón.

En este párrafo, el General Izurieta trata el orgullo marcial y patrio y, como hiciera el General Pinochet, se refiere al pueblo de Chile como una "raza" suponiendo una unidad biológica. Agrega que esta "raza" comparte el "patrimonio" de las glorias del Ejército. Los términos utilizados - unción, profundo y corazón- aluden al proceso de sublimación de las glorias del Ejército y la patria por medio de una especial devoción.

En otras secciones de su discurso, el General Izurieta se refiere al "martirio y heroísmo nacionales", a la "gesta heroica", al "sacrificio", al "valor, arrojo y desprecio por la muerte" de los combatientes chilenos. Señala que estos valores se encuentran grabados "a fuego" determinando no sólo "la conducta del soldado chileno" sino también "la estirpe guerrera de nuestro pueblo".

El sacrificio de La Concepción es representado como un evento "sublime”, un "ejemplo enaltecedor" y "un notable episodio nacional”. En sus propias palabras, sostiene, el martirio de La Concepción llena la "imaginación sobre cuán hondo pueden arraigarse los sentimientos de amor patrio, de responsabilidad cívica y de adhesión a principios inmutables, como el valor y el honor.” (Izurieta, 2007)

Los días 9 y 10 de Julio el Ejército celebra un evento cuya "magnitud" no puede ser comprendida "si se reduce a un hecho aislado de inmo- 
lación”. Se trata de una celebración que también pone en el centro el cultivo, tanto en el Ejército como en el pueblo de Chile, de una "predisposición anímica" y un "práctica de valores superiores que marcan la diferencia entre un acto irreflexivo" y temerario de mero "desprecio por la vida”, y otro que "impulsa a los hombres a sobreponerse y enfrentar con fortaleza la adversidad” (Izurieta, 2007). Según el General Izurieta (2007), tal y como hicieran los héroes de La Concepción que defendieron la bandera de Chile hasta sus últimas consecuencias, el "[e]star dispuestos a morir por Chile debe ser el sello más distintivo de cada miembro del Ejército”. En la visión patriótica impulsada está la idea de que todo chileno debe sentirse capaz de seguir el ejemplo de los héroes de La Concepción, que escribieron una "inmaculada" "página de la historia” que "todo ciudadano" debe leer y "todo corazón honrado" debe amar.

Otro tema recurrente en el DM presente a lo largo de los períodos estudiados es el de la consustancialidad o muy estrecha relación entre el pueblo y el Ejército de de Chile, los que comparten destinos. La siguiente cita del General Izurieta (2007) es representativa:

El Ejército chileno -institución que cruza transversalmente la sociedad nacional, abarcando todas sus capas- estará siempre presente compartiendo los destinos de la patria; y para ello está dispuesto a cualquier sacrificio, sea en la paz o en la guerra.

Otro tema común a los períodos analizados es el del respeto a la tradición. El General Izurieta (2007) plantea la importancia de la tradición para el Ejército, la que define como "la entrega de un acervo heroico que las generaciones pasadas hacen a las presentes para que nosotros las proyectemos al futuro." Agrega que la tradición debe fortalecerse con una "indeclinable voluntad”.

A pesar de sus diferentes énfasis, por medio del estudio inductivo de los discursos se puede ver que existen ciertos temas -códigos- que son transversales y que corresponden a rasgos comunes y continuidades semánticas del DM sobre la IN. Primero, se observa una serie de valores tradicionalistas, marciales y nacionalistas, que son un tema permanente aún cuando se expresa por medio de los términos y expresiones particulares de cada "hablante". Estas expresiones fueron etiquetadas como códigos. Cada código representa una línea temática, y debe ser capaz de condensar, ordenar y subsumir varios términos y expresiones concretas que si bien son siempre particulares, tienen suficiente similitud para evocar una misma línea temática. Entre estos códigos están la "unidad” nacional, el "actuar heroico", la "bravura”, el "arrojo”, el “carácter” y "temple” del Chileno, la valoración de la "historia patria”, el "amor" y "sacrificio" por la "patria”, y la devoción por el "interés superior” de Chile. En el Diagrama 1. Árbol de Códigos Comunes del Discurso Militar (abajo) he distribuido al lado izquierdo los códigos más directamente vinculados a valores nacionalistas marciales, al centro los que aluden a un ethos o modo de ser chileno y a la izquierda a valores nacionalistas que van más allá de lo estrictamente mar- 
cial. Como conjunto, los códigos forman una familia o árbol organizado en torno del código superior PATRIA. Este marco de interpretación está presente en buena parte de los discursos estudiados, otorgándoles de este modo una estructura general común.

\section{Diagrama 1. Árbol de Códigos Comunes del Discurso Militar}

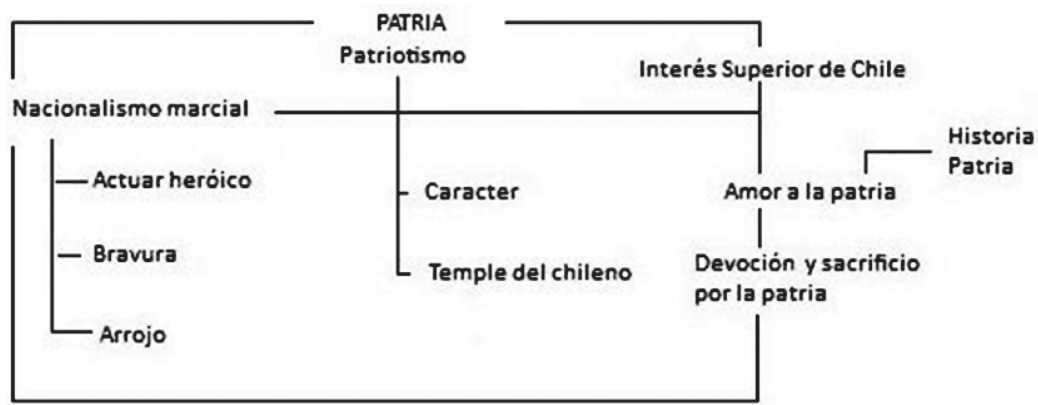

Una segunda continuidad la constituye un escenario idealizado de “unidad nacional”. En efecto, los discursos de los 3 Generales evocan vívidas imágenes de armonía social, unidad, totalidad y de (relativa) plenitud. Tales imágenes son usualmente representadas por la condensación de Chile y/o patria con otros significantes como "unidad". Chile y patria son altamente connotados por una multiplicidad de calificaciones de que son objeto. Aquí nos encontramos con un límite el análisis de contenido y la codificación inductiva que, dado su carácter hasta cierto punto positivista, sólo estudia los significados explícitos y sus relaciones. En efecto, el análisis de contenido es ciego los opuestos de Chile, patria, unidad y plenitud, los que sin embargo son evocados por la red de connotaciones latentes del DM. Esta limitación puede ser superada en parte con el uso del AED dado que presta atención a los significados que se expresan en la latencia de la estructura del discurso. ${ }^{7}$

\section{Análisis estructural del discurso militar acerca de la identidad nacional}

El AED (Martinic 1992; 2006) utiliza los principios de condensación y oposición para establecer lo que llama “códigos de base”. Estos son usualmente una oposición binaria de carácter lógico que organiza el conjunto del discurso. Cada uno de los términos de la oposición es calificado por una serie de códigos adyacentes (códigos calificativos) que le otorgan una abundancia de significación (connotación) a los códigos de base. Sin embargo, el significado de los códigos de base no sólo depende de sus rela- 
ciones con otras unidades semánticas que los afectan, sino que también depende de las jerarquías de valor que se establecen (un principio evaluativo). En consecuencia, la connotación positiva o negativa que adquiere cada término de la oposición binaria chileno y no-chileno (códigos de base) está determinada por el conjunto del discurso, tanto sus elementos manifiestos como latentes.

Los códigos de base Chileno/No-Chileno y los códigos calificativos Verdadero/Ideológico ordenan y otorgan coherencia lógica al DM sobre la IN en el período del General Pinochet. Para efectos de su presentación en la Tabla 1 he ordenado en su mayoría expresiones literales representativas de su discurso. Estas citas han sido incluidas para que el lector pueda identificar los pasos seguidos en el proceso de abstracción de los códigos que se representan en la Tabla 2, que son los más relevantes en el AED (en lo que sigue, por limitaciones de espacio nos concentraremos únicamente en los códigos).

\section{Tabla 1. Representación social del discurso sobre la identidad nacional en el período del General Pinochet (citas).}

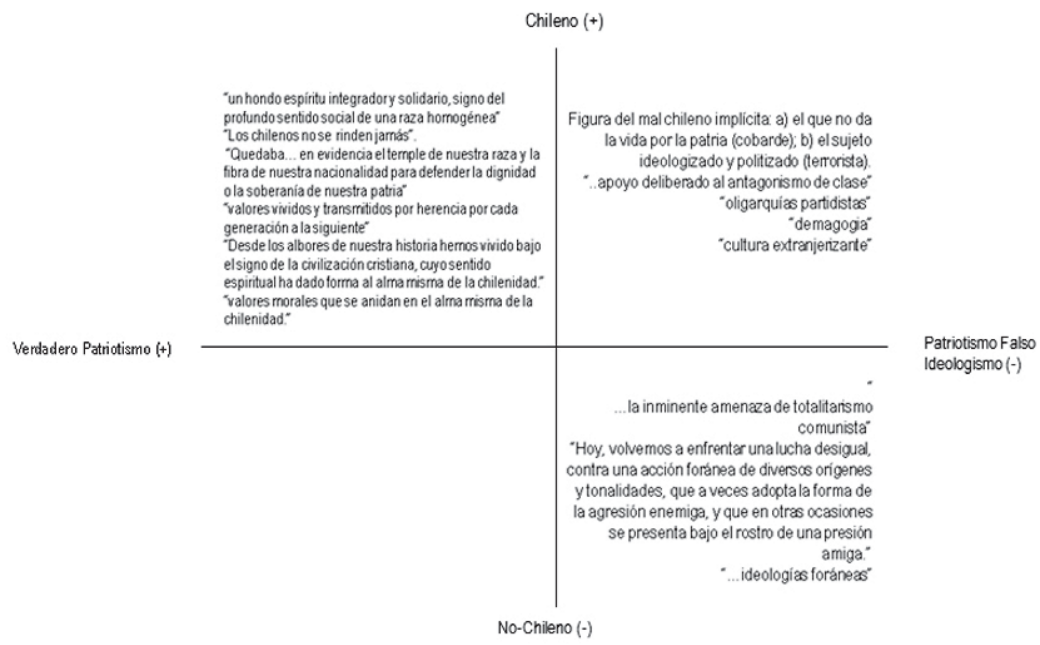

La Tabla 2 (abajo) presenta de manera similar a lo realizado en la Tabla 1 (arriba) los códigos calificativos en lugar de citas de la representación de lo chileno y lo no chileno. Mientras el cuadrante superior izquierdo contiene los códigos calificativos positivos que determinan al código de base "chileno", el cuadrante superior derecho muestra los códigos calificativos negativos, que enfatizan una serie de de imágenes del mal chileno. El cuadrante izquierdo inferior no-chileno no presenta expresiones empíricas en el discurso, pero implícitamente representa la figura positiva del extranjero. Finalmente, el cuadrante inferior derecho representa lo no-chileno 
negativo y amenazante. En el AED es importante construir los opuestos lógicos que no siempre están presentes empíricamente (comparar el cuadrante inferior izquierdo en las Tablas 1 y 2), pero que son una condición de lógica necesaria de la representación social que estructura un determinado discurso. Tal es el caso de lo opuesto a lo chileno, que requiere de una unidad identificable como un país extranjero o un conjunto de atributos que se oponen a los que se encuentran condensados bajo la noción de chileno. ¿Pero cómo tratar a los subgrupos internos que son invisibilizados por el discurso? ¿Habrá que tratar a las minorías o pueblos originarios como internos y chilenos o como externos? Volveremos a esta pregunta hacia el final de esta sección. En este caso, Chile, lo chileno, lo nacional -condensado bajo el código “chileno”- tiene una connotación positiva y se define por su oposición a su exterior, lo no-chileno.

\section{Tabla 2. Representación social del discurso sobre la identidad nacional en el período del General Pinochet (códigos).}

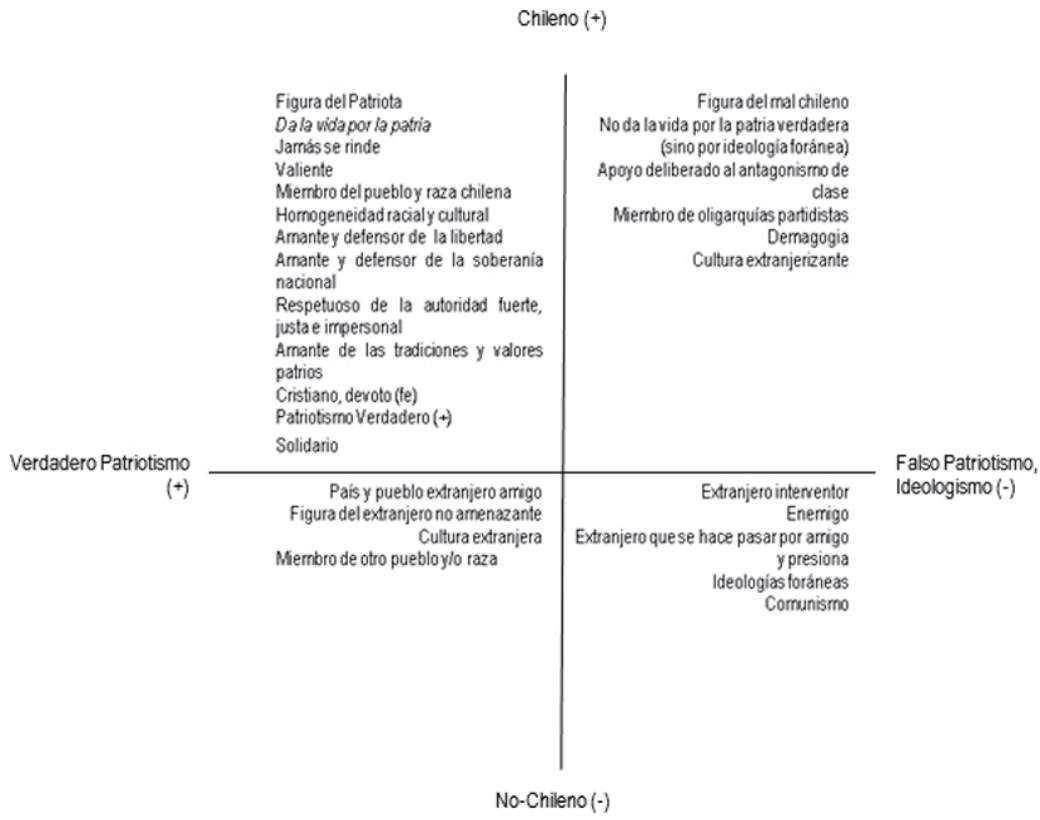

La figura del chileno patriota o un "chileno verdadero" es aquél perteneciente a una "raza" chilena mestiza, "homogénea". Es aquél que está dispuesto a "dar la vida por la patria" y que comparte los valores y tradiciones de "la chilenidad". Por otra parte, la figura del falso o mal chileno, es aquella que describe o a un cobarde, o a un sujeto ideologizado cuyo afán político sometido a ideologías foráneas que lo han desarraigado de las tradiciones y valores 
patrios. Además, el cruce de los ejes “chileno - no chileno” y "verdadero falso" le otorgan a lo chileno las connotaciones positivas de genuino, interior, propio del alma, profundo y esencial, mientras que para lo no chileno se articulan los significados negativos de exterior, foráneo, superficial, desarraigado y falso. Es interesante observar que el cuadrante inferior izquierdo es afectado importantemente por estas mismas connotaciones negativas.

La Tabla 3 a continuación presenta los códigos de base Chileno y No-en el período del General Cheyre. En este caso, el código calificativo que emergió como más relevante se refiere a la globalización y sus oportunidades y amenazas. También el General Cheyre plantea que es fundamental desarrollar el "nacionalismo”, pero este debe ser sin “exclusiones... indeseables”. Pero, ¿cuáles son los límites de este nacionalismo que uno podría llamar inclusivo, razonable y no chauvinista? Debe basarse en "un claro discernimiento de que Chile y sus intereses están primeros.” El General Cheyre afirma que “por la Patria hay que estar dispuesto a dar la vida, y ello no sólo es morir en aras de ese ideal.” Se trataría de una "renunciación diaria a cuotas de privilegio", de "rechazo al propio yo” y a las “visiones mezquinamente corporativas” (Cheyre, 2003). Alo anterior habría que agregar que, como se dijera en la sección anterior, la mayor preocupación del General Cheyre es por la mantención de una identidad histórico-cultural cohesionada -la chilenidad- en un contexto de globalización. El riesgo es, por lo tanto, perder la devoción por la patria y la capacidad de tener un sueño compartido del Chile deseado, o volverse chauvinistamente nacionalista. Los mayores obstáculos serían el individualismo, la fragmentación social y la pérdida de las tradiciones.

\section{Tabla 3. Representación social del discurso militar sobre la identidad nacional en el período del General Cheyre (códigos).}

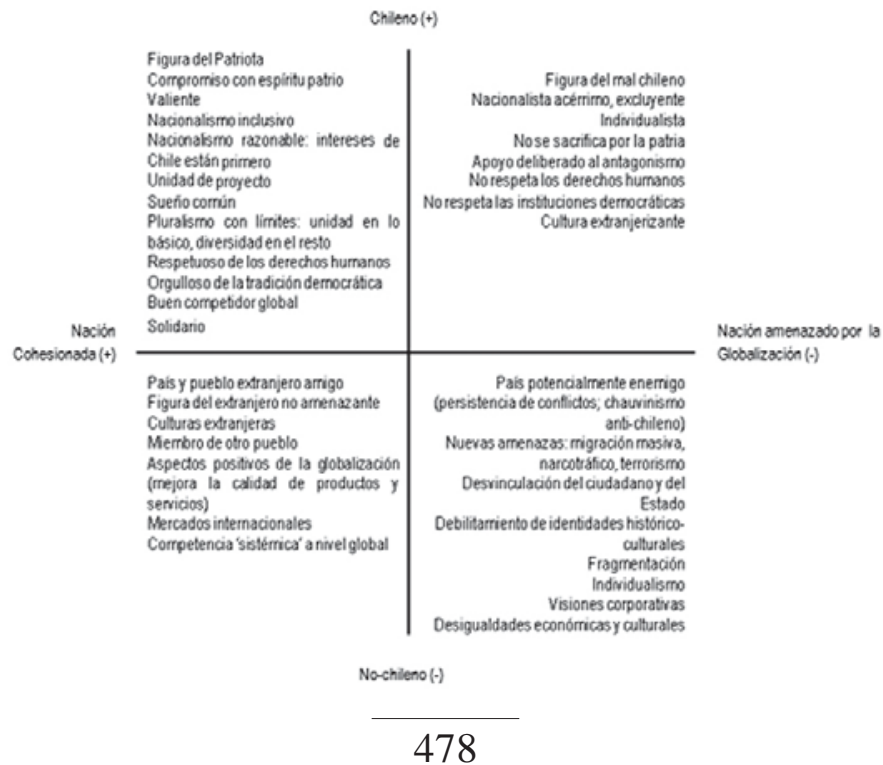


La Tabla 4 a continuación contiene los códigos identificados en el discurso del General Izurieta. En este caso, el código calificativo que emergió como más relevante es el de patriotismo y ausencia de amor patrio. Se utilizó la misma metodología para identificar a los códigos constitutivos del discurso, que en este caso enfatizan el valor de la soberanía cuya defensa se vincula al patriotismo y vuelve a destacar la noción de una raza chilena, que estaba presente en el Dm en el período de Pinochet.

\section{Tabla 4. Representación social del discurso militar sobre la identidad nacional en el período del General Óscar Izurieta (códigos)}

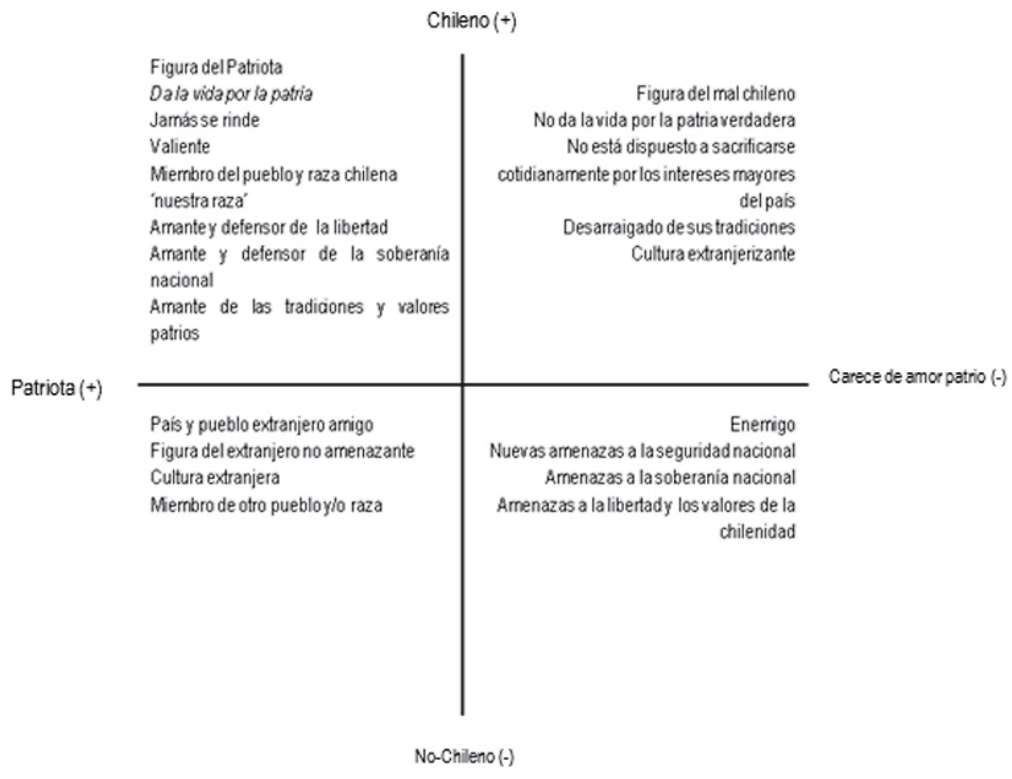

Los escenarios sociales de plenitud y figuras idealizadas del chileno presentes en las estructuras del DM que se presentaban usualmente en el cuadrante superior izquierdo de la Tablas 1 a 4 , no borran su contrario, el núcleo traumático de la IN chilena que se expresa por las figuras del mal chileno y, en ocasiones por medio de un silencio sintomático. Respecto de lo último, una continuidad del DM sobre la IN es el ocultamiento y/o no-reconocimiento de pueblos originarios y otras categorías sociales. La homogeneidad de la raza chilena enfatizadas en los períodos de Pinochet e Izurieta es ficticia, así como lo es la unidad nacional enfatizada en los tres períodos 8aunque en el caso de Cheyre de manera diferente). La referencia a la raza mestiza oculta el proceso violento en que se formó la población de Chile y su heterogeneidad. Su uso como categoría disimula las prácticas cotidianas que excluyen a algunos individuos sobre la base de diferencias fenotípicas o de linaje. Por su parte, la 
exaltación de la unidad nacional oculta los más importantes clivajes sociohistóricos, como son las diferencias ideológicas o de clase social. Ambos ocultamientos intentan neutralizar la conflictividad.

Estos silencios ocultan los traumas colectivos que constituyen y articulan la identidad nacional. En otras palabras, la IN está definida por una negatividad, por una serie de traumas que se van acumulando como capas geológicas y que tienen más o menos vigencia en cada momento histórico. Sus esferas de conflicto son diferentes, pero todos tienen en común el que reflejan el mismo antagonismo social inerradicable, que no es otra cosa que otra forma de nombrar el vacío ontológico de la identidad nacional. ¿Cómo explicar entonces que no vivamos la experiencia de ansiedad de ese aborrecible vacío? La función de la fantasía social expresada en el discurso es precisamente la de encubrir, ocultar y "ficticiamente" o "imaginariamente" llenar el vacío. Pero este proceso subconsciente no es perfecto y no logra completa efectividad. En ocasiones, especialmente en situaciones conflictivas, detectamos sus falencias y las hebras del nudo traumático se hacen visibles. También es cierto que, en su propia estructura, los elementos manifiestos de las fantasías a la vez cubren y expresan (por su ausencia) al nudo traumático de la identidad (como si se tratase de un grito silenciado). Tal es, en mi opinión el caso de la fantasía de unidad nacional y de raza homogénea presente en el DM.

El DM contiene una descripción de la IN que tiene un efecto performativo (Butler, 1990; 1993). Al describir una versión preferida de IN, el DM no sólo precede sino que, además, constituye al ser nacional patriota como aquel sujeto capaz de dar la vida por la patria. Lo inverso, es decir, un sujeto patriota anterior al discurso, es la ficción, la fantasía que el discurso nos quiere hacer creer por medio de su descripción naturalizadora. La fuerza de interpelación del $\mathrm{DM}$, a la vez nacionalista y patriótico, radica en que enseña lo que hay que hacer o estar dispuesto a hacer para ser un chileno de verdad. Esta imagen idealizada del chileno patriota no es otra cosa que una fantasía con efecto normativo. Además, ya sea implícita o explícitamente, describe las posiciones de sujeto no-chileno y aquella abyecta o indeseable: el anti-patriota. Esta estable oposición binaria chileno de verdad / no-chileno constituye una de las principales continuidades del DM sobre la IN chilena. Su funcionamiento y efectos performativos, disciplinarios y regulatorios, que favorecen la constitución de un sujeto nacional patriota, pueden postularse como constantes.

A continuación, la Tabla 5 presenta resumidamente los principales temas constitutivos de de los discursos analizados. Al ser leída de izquierda a derecha, se observan los cambios de énfasis que tuvo el DM desde el período del General Augusto Pinochet, al período de los Generales Cheyre e Izurieta. Cada Comandante en Jefe imponía una cierta impronta característica en el discurso institucional, y favorecía ciertas representaciones acerca de la patria, el sujeto nacional ideal, el otro nacional abyecto -el mal chileno-, el no-chileno y el enemigo. En la tabla se observan tanto continuidades como discontinuidades temáticas entre los diferentes períodos de comandancia en jefe. Naturalmente, estos cambios y permanencias no podían ser captadas con el puro tratamiento de cada período por separado (Tablas 1,2, 3 y 4). 


\section{Tabla 5. La Estructura del Discurso Militar sobre la Identidad Nacional en Tres Períodos (códigos)}

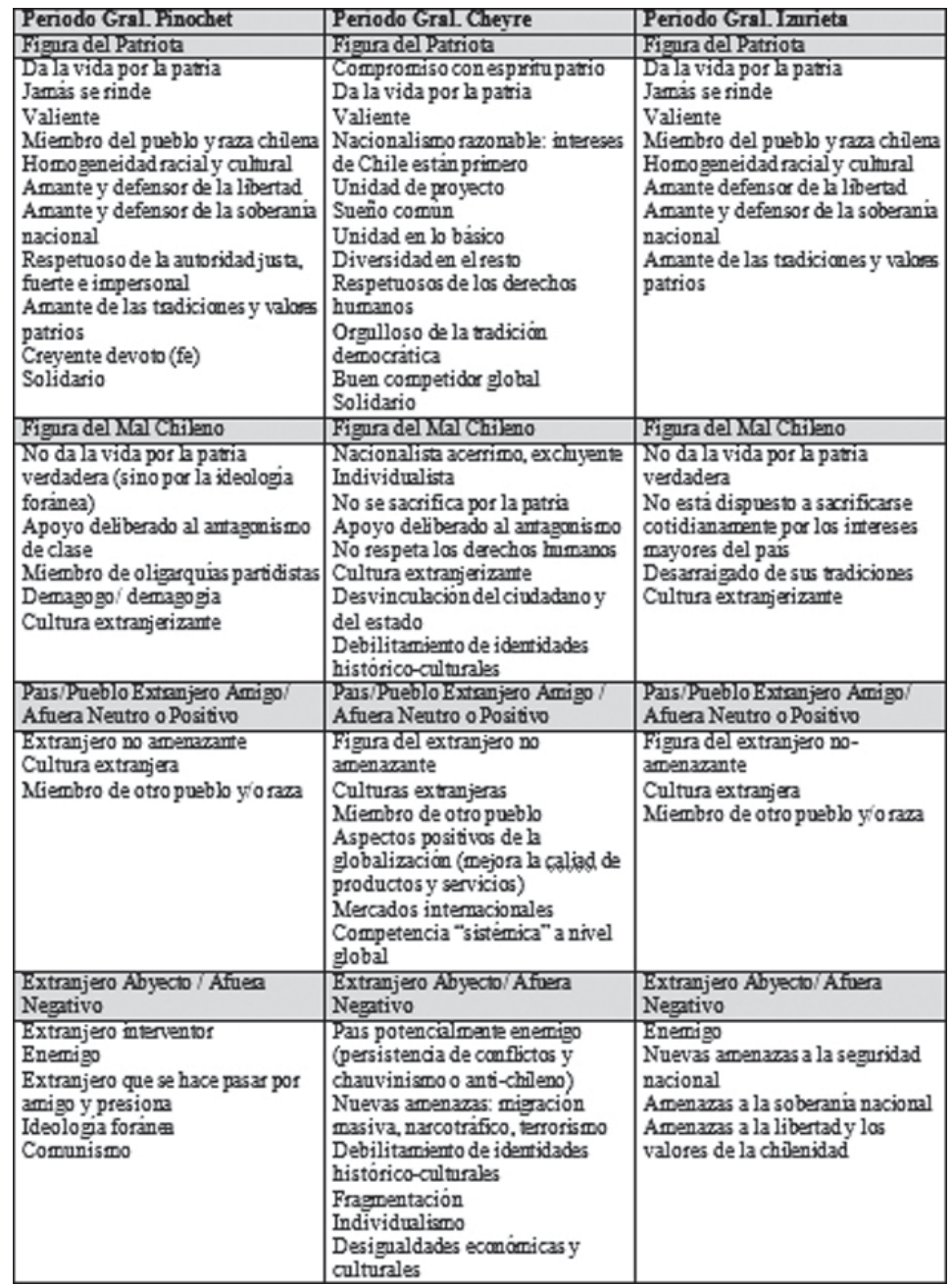

Como sucede en parte con el procedimiento de codificación inductivo, el AED tiende a fragmentar el discurso. El análisis morfológico del discurso (basado en el análisis de la ideología de Freeden 1996) ofrece como complemento el producir una aproximación de conjunto al material estudiado, tarea que abordo en la siguiente sección. 


\section{Análisis Morfológico del Discurso Militar sobre la Identidad Nacional}

El filósofo político Michael Freeden (1996) viene proponiendo desde hace un par de décadas una manera de estudiar las ideologías y el discurso político como redes o sistemas conceptuales que tienen efectos performativos en la vida política. Freeden describe los cuerpos ideológicos -o discursos- como redes conceptuales con morfologías características que son cambiantes en el tiempo. En esta sección he adaptado algunas de estas ideas para los efectos de producir un análisis más integrado de los temas constitutivos -conceptos diría Freeden- y la estructura del DM sobre la IN. La integración de los conceptos del DM en términos de morfologías discursivas me permitirá establecer comparaciones generales y describir mejor los cambios que se producen a través del tiempo en el DM. ${ }^{8}$

El diagrama 1 (abajo) presenta gráficamente las relaciones entre los conceptos más característicos del DM en sus tres momentos usando la lógica de la teoría de conjuntos. Cada conjunto -el DM de Pinochet, el de Cheyre y el de Izurieta- presenta una serie de significantes que le son característicos. Las áreas exclusivas de cada conjunto contienen aquellos significantes que son propios de cada período, mientras las áreas de intersección entre dos y tres conjuntos contienen aquellos significantes que son compartidos. El área de intersección entre los tres conjuntos contiene los conceptos nucleares Patria, Chile, patriotismo (o amor patrio) y soberanía, que son aquellos sobre los que trata más potentemente el DM y que articulan su versión de IN. El diagrama puede interpretarse también de manera diacrónica, considerando la lectura en el sentido opuesto al movimiento de las manecillas del reloj como lo indican las flechas punteadas. Así se vuelve evidente que el DM sobre la IN fue variando bajo las diferentes jefaturas, aunque se mantuvo un núcleo de significantes permanentes. Estos conceptos coinciden con la condensación "chileno" del AED presentado en la sección anterior. Alrededor de estos conceptos nucleares se ordenan una serie de conceptos adyacentes que van variando en cada período histórico.

El cambio en el DM se expresa por medio de la movilidad e innovación conceptual. En efecto, los conceptos pueden ser desplazados en el tiempo y volverse menos relevantes, o incluso desaparecer o ser reemplazados por otros a través de nuevas articulaciones discursivas. Por ejemplo, si comparamos en el diagrama 1 las respectivas morfologías del DM en los períodos de los Generales Pinochet, Cheyre e Izurieta, se observará una serie de innovaciones y reemplazos conceptuales. La figura del pueblo y el anti-marxismo, muy presentes en el DM en el período del General Pinochet pierden relevancia o desaparecen en el período de los Generales Cheyre e Izurieta. También es notable la aparición de los derechos humanos como significante importante en el período de Cheyre y su foco en la modernización del Ejército, éste último siendo un tema que comparte con el DM del período de Izurieta. Junto a estas importantes discontinuidades discursivas, 
sobresale la continuidad de los conceptos nacionalistas que se representan en el centro del diagrama en el área de intersección de los tres conjuntos discursivos. Es interesante observar que en el período del General Izurieta hay nuevamente articulaciones del concepto raza con la identidad chilena (que habían desaparecido durante el período del General Cheyre).

El DM sobre la IN define a Chile como una entidad con un núcleo esencial que se expresa en el espacio de intersección de los tres conjuntos en el diagrama 1. Chile, la patria, sería una unidad inquebrantable a la que se le atribuye una continuidad histórica que se vincula tanto a un origen primordial como a un futuro esperanzador. La fortaleza de este discurso esencialista radica en que responde a la condición ontológica de la experiencia de carencia y vacío descrita por el psicoanálisis lacaniano. Desde esta perspectiva, las afirmaciones del DM proveen de una auto-comprensión y un orden basados en una fantasía que promete un escenario idealizado de plenitud, unidad, continuidad histórica y consistencia valórica.

\section{Diagrama 1. Morfología del Discurso Militar sobre la Identidad Chilena en Tres Períodos}

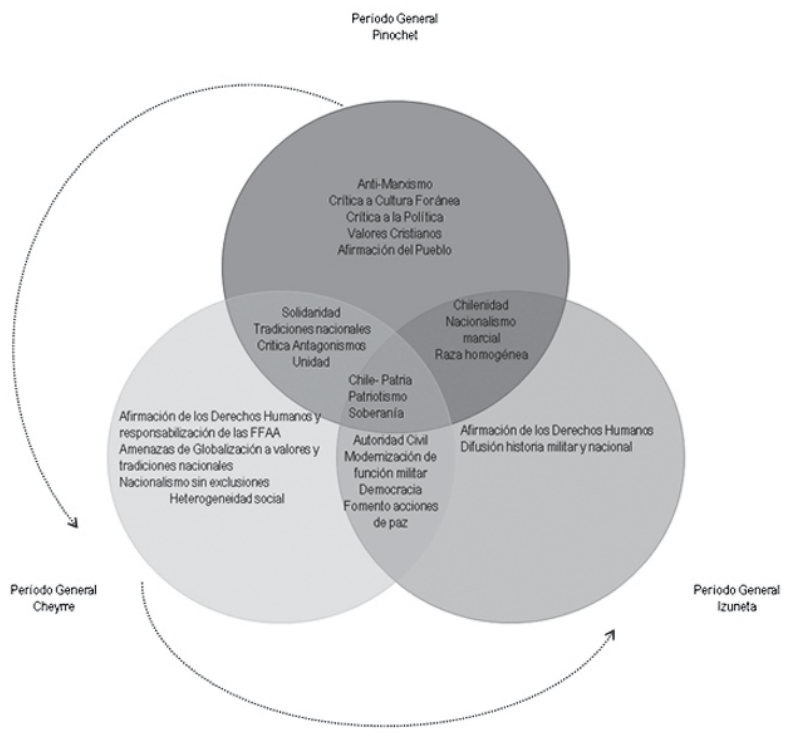

En las siguientes secciones veremos cómo se estructura el DM acerca de la IN sobre la base de una particular economía libidinal. 


\section{Identificación, catexis e introyección}

El discurso del General Pinochet pronunciado en la ceremonia del 9 de Julio de 1977, invitó a 77 jóvenes ejemplares según los criterios de la dictadura, y por medio de su compromiso interpeló simbólicamente a la juventud Chilena, aspirando a su identificación con el acto patriótico de los 77 jóvenes mártires de La Concepción.

1

\begin{abstract}
Mi corazón de viejo soldado revive con profunda emoción el coraje insuperable de Luis Cruz Martinez y de los otros 76 jóvenes chilenos, que junto a él, en plena soledad de la sierra peruana, supieron demostrar con la entrega de sus vidas, que nuestra Patria y los valores permanentes del espiritu están por encima de cualquier sacrificio personal que su defensa pueda demandar. (Pinochet, 1977)
\end{abstract}

Estas palabras del Discurso de Chacarillas buscan generar sobrecogimiento, emoción y orgullo patrio. El discurso tiene una importante densidad significativa. La importancia de la identificación con los héroes rebasa lo puramente individual cuando observamos que los individuos construyen sus identidades personales sobre la base de materiales culturales con significación social, como es el discurso nacionalista. El discurso aspira a lograr el auto-reconocimiento de los sujetos con la versión de IN que favorece. Su connotación se prolonga por medio de una intertextualidad que articula tres eventos discursivos: la conmemoración de La Batalla de la Concepción ocurrida los días 9 y 10 de Julio de 1882, el día del Juramento a la Bandera (ceremonia militar), y un acto de carácter cívico en que se presentaron algunos de los lineamientos ideológicos y políticos más sobresalientes del régimen militar y el tipo de orden institucional al que éste aspiraba. Esta condensación de acto comunicativo, práctica ceremonial y artefactos simbólicos tomó la forma de un rito televisado. La ceremonia creaba performativamente lo que refiere. Nombró y premió a 77 ilustres jóvenes líderes del régimen y creó así una generación de fervientes seguidores, devotos de los valores patrios análoga a la de los 77 héroes que murieron en la Batalla de la Concepción. La ceremonia también objetivó por medio de la reiteración y la cita una explicación del proceso de quiebre de la vieja democracia y, con la misma estrategia discursiva, ofreció una descripción de los valores verdaderos que servirían de fundamento a la nueva democracia protegida que debía emerger.

Otro aspecto interesante es que Pinochet se identifica con el Subteniente Luis Cruz Martínez por medio de sus palabras que representan sobrecogimiento y admiración hacia el más joven de los así ungidos "mártires de La Concepción” (1-2).

$\mathrm{Al}$ mencionar la sierra peruana sugiere quién es el enemigo, ese otro frente al que la identidad propia se define: el Perú (3). Además, describe el atributo fundamental de devoción a los "los valores permanentes del espíritu”. Esta fórmula no expresar nada con precisión, pero contribuye a cons- 
truir un significante ambiguo. De este modo, los distintos observadoresreceptores podían proyectar sus propios sentidos preferidos. Este mecanismo retórico pretende inducir a la devoción por la causa patriótica. Recordemos que una versión de identidad colectiva que pretende ser exitosa debe aspirar a ser creíble y palpitante de modo que las personas la vivan activamente y la recreen por medio de sus identificaciones, su auto-comprensión, sus conversaciones y sus prácticas más cotidianas. En síntesis, la formación de la identidad individual y grupal ocurre como resultado de una compleja dialéctica entre interpelación del discurso e identificación del sujeto.

Lo que pensamos y decimos acerca de la nación chilena y lo que hacemos en relación a ella está sobredeterminado. Esto es, depende de imágenes y sistemas de representación simbólica que son exteriorizados e introyectados y que hacen posible al sujeto tener una imagen de lo que la nación chilena es. El proceso de interpelación/identificación aquí descrito aspiraba a que el sujeto, que está marcado por el vacío y la falta (manque), asimilara un aspecto, una propiedad, o un(os) atributo(s) de otro sujeto, en este caso, el sacrificio y amor patrio de los héroes de La Concepción. El individuo identificado con la patria, asimila sus símbolos y valores, y los inviste de energía libidinal (catectización). ${ }^{9}$ La asimilación del discurso nacionalista y la identificación con sus valores virtualmente llenan el vacío del sujeto. Este acto de asimilación es requerido debido a que el vacío del sujeto es intolerable. Así, la identidad del sujeto se transforma, total o parcialmente, sobre la base del modelo de otro sujeto u objeto con el que se produce la identificación (el héroe). Cuando hay identificación se produce una introyección, es decir, se hace pasar de forma fantaseada al adentro de la realidad psíquica del sujeto objetos o atributos de objetos ubicados afuera.

¿Es posible vincular el proceso de identificación que he descrito con la noción lacaniana de sublimación? En la sublimación lacaniana lo que está en juego es la elección de un objeto a, es decir, un objeto amado, Chile en este caso, que acumula un surplus de significación y que es investido a grado tal que se produce una elevación de su status $(\bullet i \bullet e k, 1989)$. El amor a la patria hasta el sacrificio representa esta catectización que inviste con sublimes afectos la relación con Chile, el territorio, la cultura propia, las generaciones pasadas y futuras, las tradiciones y los valores nacionales. Chile-patria es un significante estructurante clave, común a ambos momentos estudiados del DM.

\section{Afectos, nación y patriotismo en el discurso del Ejército de Chile}

Más que una adhesión puramente cognitiva a un proyecto nacional, el nacionalismo/patriotismo constituyen una adhesión afectiva a una creencia de pertenencia a una comunidad de sentimientos, por lo que se parece 
más a la religión que a las ideologías racionalistas como el liberalismo o el socialismo (Anderson, 1993; Hobsbawm, 2000). El amor a lo propio y el odio a intervenciones foráneas pueden adquirir importancia en la lucha política. La idea de nación sea especialmente apetecida por los diferentes proyectos políticos (que son también frecuentemente económicos, sociales y culturales). En su afán por lograr la hegemonía política, no es raro encontrar proyectos que elaboran conexiones ideológicas con la noción afectiva de nación, anclando sus ideas e intereses en la noción inclusiva, vaga y englobadora de nación o patria. Así logran estabilizarse y articularse con los sentimientos más profundos de los grupos. Un buen ejemplo es el de la declaración de principios del Gobierno Militar (Pinochet, 1974), representativo del DM sobre la IN en la época:

La integración espiritual será el cimiento que permitirá avanzar en progreso, justicia y paz recuperando el lugar preponderante que los forjadores de nuestra República le dieron en su tiempo en nuestro continente. Reivindicar y sembrar en el corazón de cada chileno el ejemplo de nuestra Historia Patria, con sus próceres, héroes, maestros y estadistas, debe transformarse en el acicate más poderoso para despertar el verdadero patriotismo, que es amor entrañable a Chile y deseo de verlo nuevamente grande y unido. Conspiran en contra de esa unidad las ideologias foráneas, el sectarismo partidista, el egoismo 0 antagonismo deliberado entre las clases sociales, y la invasión cultural extranjerizante.

Este discurso político particular sólo podía aspirar a expresar una versión singular de la IN y, no obstante, intentó interpelar a públicos amplios más allá de sus seguidores leales. Para que ello fuera creíble, los intereses particulares del régimen militar y sus aliados se rearticularon en un discurso más inclusivo capaz de representar simbólicamente al menos los intereses de las mayorías. De otro modo, su versión discursiva de identidad no habría logrado aceptación alguna y habría fracaso desde el inicio. La recuperación de la “integración espiritual”, “el progreso”, la “justicia” y la “paz” (1-2) precisamente expresan la pretensión de integración nacional de quienes estaban divididos. También interpela a los contemporáneos apelando al testimonio de amor patrio y los sacrificios de los padres de la república y los héroes nacionales que fundaron la unidad y grandeza de Chile (2-7). Este párrafo invita explícitamente a la identificación con ese ejemplo de dedicación a la patria (5-7). La fantasía de unidad nacional está anclada en un pasado de grandeza que se constituye en un mito fundacional de la República. La fantasía promete la recuperación de la continuidad pasado-presente-futuro de la nación chilena.

Como toda fantasía, ésta tiene su lado negativo que expresa aquello que obstaculiza la realización del escenario ideal: la plenitud y unidad de la patria. ¿Cuáles son estos obstáculos?: Las “ideologías foráneas”, “el sectarismo partidista”, “el egoísmo o antagonismo entre las clases sociales” y la influencia de una "cultura extranjerizante” (7-10). También es interesante 
observar cómo la división interna es asociada a lo foráneo, las ideologías y la invasión cultural. Esto funciona como una proyección, es decir, como una operación por medio de la cual se expulsan fuera de la propia identidad atributos u objetos que se rechazan o que no se quiere reconocer como parte propia. De este modo se afirma la unidad y mismidad monolítica de la nación chilena, y se critica la heterogeneidad y diferencia.

Por otra parte, la versión de IN promovida durante el régimen de Pinochet debió mantenerse fiel a buena parte de los intereses fundamentales de su bloque de apoyo autoritario para no desnaturalizarse. Por ello, el discurso pone del lado de "las tradiciones" que son "las constantes de nuestra historia" al orden capitalista, al respeto por la propiedad privada y el rol subsidiario del estado, todos ellos representativos de intereses particulares.

Es importante recordar que la función principal de la fantasía social es la de domesticar la pulsión enseñarnos qué y cómo desear. Tanto la afirmación del escenario idealizado como aquello que lo obstaculiza son parte de la fantasía y ambas son funcionales a la estabilidad social. Mientras el escenario idealizado es una promesa de satisfacción del deseo, señala lo que debe ser alcanzado y compensa la experiencia de necesidad, el obstáculo de la fantasía otorga una explicación a la frustración haciéndola más tolerable y señala aquello que debe ser vencido como un enemigo. De este modo el problema no está en el objeto del deseo escogido, es decir en la IN fundada en valores esenciales, en las tradiciones y la unidad y continuidad histórica que éstas aseguran. El problema se desplaza así a aquello que imposibilita su logro: las ideologías foráneas, la cultura extranjerizante, las divisiones de clases y partidistas.

Para el gobierno militar del General Pinochet este discurso funcionó inicialmente como un factor facilitador pues, como todo régimen de fuerza su principal recurso de poder y mecanismo de reproducción fue la coerción en vez de la legitimación. Ahora bien, como el gobierno militar aspiraba a reformar profundamente el país y refundar el orden político, debía aspirar a ganarse las mentes y los corazones de las personas; un objetivo ideológico de largo plazo que no era otra cosa que construir un nuevo orden hegemónico que incluso pudiera sobrevivir al gobierno militar manteniendo los pilares del nuevo orden.

Parte de este nuevo orden fue la llamada Constitución de 1980. En un discurso del 11 de marzo de 1981 que inaugura su período presidencial, el Presidente Augusto Pinochet funda el nuevo orden constitucional en las tradiciones y en un futuro esperanzador:

"Este mismo pueblo cruza el umbral de un nuevo sistema político, y lo hace lleno de fe, esperanza y confianza en su futuro" (Pinochet, 1981)

Desde los 1970 a la actualidad se producen importantes acomodos 
en el discurso de los Generales en Jefe para enfrentar las cambiantes coyunturas históricas, para mantener su capacidad de interpelación y de producir amplia identificación de la población. Entre las comandancias en Jefe posteriores a la salida de su cargo del General Pinochet, la del General Juan Emilio Cheyre me parece especialmente renovadora, razón por la que ha sido escogida para un análisis más detallado. Sin embargo, como se observará, la continuidad de ciertas temáticas y un ethos conservador mantienen un mismo hilo conductor.

\section{La versión esencialista de identidad nacional del Ejército de Chile}

La concepción esencialista de las categorías sociales supone pensar en una serie de rasgos fijos e inalterables, desatendiendo así la historicidad, complejidad y la heterogeneidad. Cuando se trata de una IN como la chilena, lo que se desatiende es la diversidad de modos de vida que se expresan en el país (Larraín, 1996; 2001; PNUD, 2002). Al respecto, Jorge Larraín afirma que desde esta perspectiva la IN se piensa "como un hecho acabado, como un conjunto ya establecido de experiencias comunes y de valores fundamentales compartidos, que se constituyó en el pasado, como una esencia inmutable, de una vez para siempre.” (2001: 143). También Bernardo Subercaseaux define críticamente la noción de IN esencial como un discurso que se refiere a "un conjunto de rasgos más o menos fijos, vinculados a cierta territorialidad, a la sangre y al origen, como una esencia más bien inmutable constituida en un pasado remoto, pero operante aún y para siempre.” (1999: 150). Los críticos de las versiones esencialistas de identidad sostienen que el esencialismo es una visión profundamente ahistórica, que no reconoce que la IN está en continuo movimiento y que va cambiando con las nuevas generaciones en su contacto con nuevas realidades históricas. Esta aversión al cambio las convierte en conservadoras pues desde este punto de vista toda alteración de la IN es percibida negativamente ya que "la identidad implicaría siempre continuidad y preservación de ciertos rasgos acrisolados en el pasado; se vería, por ende, continuamente amenazada por aquello que implica ruptura, pérdida de raíces...” (Subercaseaux, 1999: 150). La siguiente cita del General Cheyre (2003) es interesante pues enfatiza la función de defensa del legado histórico, los valores y tradiciones patrios inmutables que dan su carácter al pueblo chileno (2-4).

... el Ejército de Chile, en conjunto con la comunidad de la que forma parte, y desde

2 el ámbito de su competencia, está comprometida en la preservación del legado

3 histórico y cultural del pais, y en la mantención de las tradiciones que han forjado la

4 nacionalidad chilena, cooperando a renovar, afirmar y proyectar, de un modo

5 integrador, especialmente en las nuevas generaciones, las virtudes civico militares

6 propias de nuestra idiosincrasia 
A mi modo de ver, además del énfasis en las tradiciones y el legado histórico transmitido por el Ejército otros dos aspectos merecen especial atención en esta cita. Primero, el modo en que el General en Jefe vincula el Ejército y la comunidad nacional de modo orgánico. El Ejército es una parte que comparte los fundamentos de la comunidad nacional. El segundo aspecto dice relación con la promoción entre las nuevas generaciones de las virtudes cívicomilitares del Ejército que son vistas como propias de la idiosincrasia nacional.

En esta perspectiva las tradiciones aparecen como perpetuas y parecen transmitir un legado histórico congelado. Pero como el cambio es innegable, usualmente los esencialistas deben argumentar de algún modo que éste no modifica su contenido profundo y auténtico. El argumento esencialista recurre entonces a la idea de alienación, que no es otra cosa que un extrañamiento respecto de la verdadera identidad, o su extravío, pues al ser esencial esta nunca puede desaparecer completamente (Larraín, 1996: 217).

Este patrón general de las visiones esencialistas se manifiesta en la versión de IN del Ejército de Chile que entre sus funciones identifica la de salvaguardar y mantener vivo el legado de valores, tradiciones y principios patrios. En un discurso relativamente reciente, el General en Jefe Juan Emilio Cheyre mantuvo que la misión del Ejército es concebida como íntimamente relacionada a los principios republicanos

... no hay República si es que no se basa en virtudes y valores a los cuales tenemos que adherir quienes formamos parte de una misma Nación. Y esas virtudes y valores son los que tratamos de vivir en el Ejército. No nos creemos poseedores exclusivos de ellos, pero sí tratamos de ser consecuentes con ser expresión de ellos (Cheyre, 2005).

Los valores y principios patrios a que adhiere y que promueve el Ejército aseguran la cohesión social de la nación en el marco del proceso de globalización que los amenaza. Pero esta es una tarea ciudadana y común a los chilenos razón por la que el General Cheyre afirma que

... lo que hace ser un mejor ciudadano de ese mundo globalizado y hacer un aporte mejor a ese mundo globalizado es el reconocer una propia identidad más allá, que es la identidad del ser nacional (Cheyre, 2003).

La IN es concebida como el límite de la globalización y, a su vez, como la manera más adecuada de insertarse globalmente pues implica la mantención de lo propio y el auto-reconocimiento que es fundamental para evitar la alineación.

\section{Ejército y comunidad nacional}

En su autocomprensión, el Ejército de Chile se ve como legítimo depositario y defensor de esos intereses toda vez que su "origen se remon- 
ta, incluso, antes del nacimiento del propio Estado chileno” (Cheyre, 2006). Nótese que el Ejército parece sostener que el nacimiento del Chile como nación organizada en un Estado es coincidente o incluso posterior al Ejército de Chile y que, por lo tanto, éste último puede bien ser su antecedente y productor. Aquí vemos como la relación entre Ejército y Nación es concebida desde el punto de vista de la pregunta por el origen: la genealogía de la nación chilena coincide con la genealogía del Ejército de Chile. En otro discurso, el General Cheyre sostiene que “... la relación ejército-sociedad podría describirse como un espejo reflector, donde hay un reflejo constante de una sobre la otra...". ${ }^{10}$ Por su parte, en el discurso del General Pinochet, el Ejército se vincula orgánicamente a la comunidad nacional. Esta relación se expresa cuando señala que "Las Fuerzas Armadas y de orden no son otra cosa que su pueblo en armas.”11

Existe una diferencia de énfasis entre las visiones de los Generales Cheyre y Pinochet. Mientras el segundo define la relación como orgánica y de consustancialidad, el primero la define de manera mimética. Ambas son fuertes metáforas de vínculo, pero sólo la primera intenta persuadir acerca de la existencia de un mismo cuerpo nacional popular.

Volvamos por un momento a la misión del Ejército. Las declaraciones de misión y visión de futuro son especialmente importantes en las instituciones y organizaciones contemporáneas pues reflejan de manera explícita el centro de su auto-comprensión, su funcionalidad y su dirección estratégica. Como se verá, también en esta dimensión podemos identificar la autocomprensión del Ejército de Chile como basada en una relación orgánica con la comunidad nacional a la cuál debe defender. Esta es declarada de la siguiente manera en el sitio web oficial de la institución:

La razón de ser del Ejército es contribuir de manera fundamental a preservar la paz, y su misión primordial es garantizar la soberania nacional, mantener la integridad territorial y proteger la población, instituciones y recursos vitales del pais, frente a cualquier amenaza o agresión externa ... su misión apunta a prevenir un conflicto, disuadiendo a cualquier potencial adversario y, si es necesario, neutralizándolo, con el propósito de resguardar la soberania y mantener la integridad territorial de nuestro pais. Además ... el Ejército participa y contribuye de diversas formas, y con variada intensidad, en el desarrollo económico y social del pais, dentro del orden juridico, sin desnaturalizar su función primordial. Asimismo, efectúa labores de resguardo y apoyo durante los estados de emergencia interna o de catástrofes naturales, de acuerdo a normas constitucionales especificas que regulan su ejecución.

Como se desprende de la cita anterior, las nociones de soberanía, territorialidad y protección de la población y recursos vitales se encuentran estrechamente vinculadas a la función de logro de la paz y defensa nacional (1-4). De este modo, sus funciones son vinculadas de modo fundamental a ciertos marcadores de identidad como la integridad territorial y la población 
nacional, a ciertos intereses nacionales como los recursos naturales y a ciertas categorías fundamentales de la noción del estado moderno como son el poder soberano y las instituciones. Y aunque la función sea la mantención de la paz, su misión también expresa la necesidad de "prevenir un conflicto" con "cualquier potencial adversario” por medio de la disuasión y “si es necesario, neutralizándolo, con el propósito de resguardar la soberanía y mantener la integridad territorial de nuestro país.” (5-8). Todos estos conceptos requieren naturalmente de una otredad explícita o implícita con sus propios estados nacionales, sus territorios, sus intereses y poder soberano que pueden volverse amenazantes y de los que Chile se distingue.

En términos de su visión de futuro, el Ejército aspira a ser una organización militar "para el combate; eficaz y eficiente en la disuasión y la cooperación internacional, polivalente, interoperativo, actualizado y sustentable; con una adecuada capacidad de gestión; con un actuar funcional y valorado por la sociedad a la cual sirve." ${ }^{2}$ Este último aspecto de la visión de futuro del Ejército es muy importante si se considera el pasado reciente de la Historia Chilena en que las Fuerzas Armadas constituyeron el principal pilar de un cruel dictadura militar. Esto también se expresa de manera indirecta en las líneas 9 a 12 cuando se afirma que “el Ejército participa y contribuye de diversas formas... en el desarrollo económico y social del país”, pero siempre "dentro del orden jurídico” y "sin desnaturalizar su función primordial”.

\section{Nosotros, ellos y la construcción de fronteras}

La identidad cultural, que es una objetivación y un artefacto social, se constituye y se diferencia de otras identidades mediante una serie de identificaciones y desidentificaciones. Desde este punto de vista, la identidad se construye dentro del discurso y la esfera de la representación, y no fuera de ellos. Así, cada chileno se relaciona de un modo imaginario por medio de la identificación con sujetos, objetos y atributos asumidos como chilenos y de diferenciación con respecto a aquellos que no son considerados chilenos. Uno de los mecanismos más sobresalientes en que este proceso toma forma es el establecimiento de fronteras entre un nosotros y un ellos (Laclau \& Zac, 1994; Mottier, 2000). Autores como Butler (1990; 1993), Laclau (1990), Hall (2003) y •i•ek (1994) han sostenido que toda identidad es relacional y que su formación es un proceso permanente de identificaciones y desidentificaciones sucesivas. Como consecuencia, la significación de la identidad chilena es, antes que todo, histórica, y no se deriva de supuestos atributos esenciales, sino de las relaciones que establece y que la constituyen como diferente de otras identidades, como las de nuestros países vecinos y otras culturas. Este mecanismo de identificación (con atributos propios) y diferenciación (respecto de atributos de otros) opera por medio del establecimiento de exclusiones (de los otros), las que son inevitables, pues lo propio de la lógica de la formación de identidad es el establecimiento de fronteras culturales entre nosotros y ellos, lo propio y lo marginado, lo apropiado y lo abyecto, adentro y afuera, y que pueden expresarse 
también como fronteras políticas, territoriales, ideológicas e incluso morales. ${ }^{13}$ Las fronteras culturales y sus criterios de inclusión y exclusión conforman tanto a los miembros de la comunidad como a aquellos que se consideran extranjeros, abyectos o desviados. Este mecanismo es crucial para establecer un sentido del orden y la estabilidad en la comunidad. Identidad y diferencia son en consecuencia sólo dos caras de la misma moneda.

La formación de identidad ocurre como un proceso de diferenciación respecto de un otro excluido, que no obstante es necesario para construir el nosotros (Hall, 2003; Laclau, 1990; Laclau \& Zac, 1994; •i•ek, 1994). Este otro puede tener referentes internos, como el revolucionario, el terrorista, el mapuche, el homosexual, etc. Respecto de los referentes externos, el otro puede ser el inmigrante, el asilado o el extranjero, especialmente aquél con quien tenemos una relación ambivalente de cercanía y rivalidad, como ocurre frecuentemente con las culturas de países vecinos. La exclusión del otro oculta las fisuras de la IN, que nunca es monolítica aunque así se represente. El permanente retorno perturbador de la exclusión (Hall, 2003: 35) se manifiesta en la cotidiana incomprensión de las culturas extranjeras, de los inmigrantes, las subculturas juveniles y las minorías sexuales, étnicolingüísticas o de pueblos originarios. Frecuentemente la cultura dominante representa a estos grupos conflictivos, desviados de la norma, irracionales, incomprensibles y hasta violentos. Esta creación "facilita una aparente cohesión del nosotros, a través de una identificación proyectiva de tales conflictos hacia ellos, los que se mantienen reprimidos y negados en el propio grupo" (Gissi, 2000: 175).

La formación del estado nacional, el establecimiento de sus fronteras y la formación de la nación chilena están muy relacionados a las guerras del siglo XIX: de emancipación de la Corona Española, contra la Confederación Peruano Boliviana, la Guerra contra España, la Guerra del Pacífico o del Salitre y la eufemísticamente llamada Pacificación de la Araucanía (Góngora, 1988). Las guerras ayudaron a establecer los límites a la vez geográficos y culturales del Chile contemporáneo. Además, al haber enrolado a numerosos hombres en una milicia les otorgó un sentido de pertenencia a una misma patria, una misión, un uniforme y una identidad común. De este modo, la IN se constituyó parcialmente a través de un ejército nacional y en contraposición a otros enemigos: españoles, peruanos, bolivianos, mapuches.

Es importante recordar eso sí que no toda relación con un otro es una relación marcada por una pasión negativa como el odio o el rechazo (que tiende a la diferenciación). También hay otros que son investidos de afecto, con los que se establece una relación positiva. Ambos polos interactúan en la constitución de las identidades colectivas. Larraín (1996; 2001) distingue a los "otros significativos" que son positivos y cuyas opiniones o modelos introyectamos, de los “otros de diferenciación”, cuyos valores no compartimos o rechazamos agresivamente. 


\section{Conclusión}

A pesar de los importantes cambios discursivos sufridos a lo largo de varias décadas, el DM sobre la IN ha mantenido su rasgo conservador basado en una ontología social esencialista. Esto es, representa como natural, esencial, unitaria e incambiante a la nación chilena. De este modo, lo que en realidad es contingente, es representado como totalidad plena por medio de los significantes "nación”, "patria”, "pueblo chileno” y "Chile”. El DM inviste esos significantes de energía libidinal, sublimándolos en el sentido antes explicado. Por su parte, estos funcionan como puntos nodales que estabilizan el DM sobre la identidad nacional. Sin embargo, su estabilización es parcial pues, como se demostró, hay cambios de énfasis y ciertos conceptos, ideas y términos son desplazados, otros desaparecen y otros nuevos son introducidos.

Tal es el caso del desplazamiento de la idea de raza chilena y su desaparición incluso durante el período del General Cheyre para luego ser reintroducido su uso en el período del General Izurieta. Otro destino sufrió el anti-marxismo del período del General Pinochet, que desapareció (en tanto elemento explícito) del discurso en el período de los Generales Cheyre e Izurieta. Otro tipo de cambio relevante es el de la introducción o innovación discursiva. Tal vez lo más interesante a este respecto sea la introducción de los derechos humanos durante el período del General Cheyre.

A lo largo del artículo se afirmó que, a pesar de los intentos de naturalización y esencialización de la versión militar, la IN es un artefacto social contingente que es discursivamente construido cuya realidad es imaginaria, por lo que pertenece completamente al campo de la representación simbólica. Pero esto no debe llevarnos a pensar que por ser imaginaria presenta debilidad o carece de efectividad histórica o de estructura. El poder, la sedimentación y cristalización del discurso y su institucionalización proveen de estabilidad a la versión militar de identidad nacional. Por otra parte, la IN es una respuesta a una necesidad existencial de los individuos: otorga orientación y un punto de referencia cotidiano, un sentido y un sentimiento de pertenencia común, y provee un horizonte de contenidos e imágenes que hacen posible habérselas con la dimensión traumática de la identidad. La representación de la IN como totalidad y unidad patria es atractiva para los proyectos ideológicos de diferentes fuerzas políticas. Por ello, frecuentemente intentan articular los contenidos particulares de sus discursos con la idea de nación y anclarlos en alguna versión sedimentada de identidad nacional.

La identidad nunca es plena. Esa carencia gatilla y moviliza nuestro deseo por construir una IN de carácter esencial que nos entregue una clara imagen de quiénes y cómo somos, que nos otorgue una auto-comprensión en la que podamos encontrar seguridad y estabilidad. Es decir, una versión de identidad completa y plena. La versión esencialista de identidad del Ejército está vigente en la lucha por el sentido de la IN debido a que responde a la necesidad existencial por cubrir el vacío en nuestra identidad colec- 
tiva. Un discurso como el del Ejército de Chile ofrece una fantasía encubridora y compensatoria de esta IN conflictuada, traumatizada, e incompleta. El DM chileno ofrece una versión ejemplar de IN que enfatiza la continuidad y plenitud de la chilenidad en la historia, naturalizándola, cristalizándola y sedimentándola.

No obstante, la marca o división interna de la identidad nunca desaparece completamente; siempre algo se escapa al control del discurso y, por lo mismo, la identidad nunca cristaliza totalmente. Todos los esfuerzos por cubrir el trauma están destinados al fracaso, pues éste no es un accidente histórico que pueda ser superado sino que es el rasgo de negatividad constituyente de toda identidad. En otras palabras, el carácter traumático de la identidad colectiva es ontológico y las crisis históricas, grandes conflictos o divisiones sociales son sus expresiones sintomáticas.

La IN es inseparable de la pregunta por el nosotros como opuesto a otros. Esta dimensión de antagonismo constitutiva de la identidad es especialmente visible en el DM que se auto-afirma y justifica en la defensa de la identidad frente a riesgos y amenazas. Las identidades colectivas implican la representación de una cultura relativamente común y diferenciada de otras culturas. En ocasiones esta representación adquiere rasgos de esencialismo en su intento por ocultar el nudo traumático constitutivo de la identidad. Entre las posibles versiones identitarias, las esencialistas intentan ocluir o cerrar otras posibles versiones y limitan la conciencia acerca de la dimensión traumática constitutiva de la identidad. Si bien toda versión de identidad expresa fantasías que intentan enmascarar la conflictuada identidad chilena, las esencialistas son especialmente excluyentes y por lo mismo inconvenientes para una sociedad democrática y pluralista.

La dimensión homogeneizante del DM identitario es expresión de una selección de materiales que provienen de los modos de vida existentes en la base social. No es pura imposición de contenidos desarraigados en la cultura nacional, sino una selección que define ciertos rasgos existentes como esenciales de la IN. Tal selección implica la exclusión (no-selección) de otros materiales significativos, valores e ideas que se representan como exteriores de la comunidad nacional. Este proceso de selección/exclusión es consustancial a toda identificación y constitución de otro, sea este ideologías foráneas (marxismo-leninismo), los países extranjeros y o las amenazas o riesgos de la globalización. Las diferencias con los otros se representan de manera exagerada en ciertas coyunturas históricas para acentuar la identidad propia o la unidad nacional. 


\section{Notas}

${ }^{1}$ Augusto Pinochet Ugarte fue Comandante en Jefe del Ejército de Chile desde el 23 de Agosto de 1973. Luego del golpe de estado que condujo el 11 de Septiembre de ese año, asumió el gobierno como Presidente de la Honorable Junta Militar hasta 1981. Fue luego Presidente de la República hasta el 11 de Marzo de 1990. Se mantuvo como Comandante en Jefe del Ejército de Chile hasta el 11 de marzo de 1998.

${ }^{2}$ Juan Emilio Cheyre fue Comandante en Jefe del Ejército de Chile entre el 11 de Marzo de 2002 y el 11 de Marzo de 2006. Su sucesor fue Óscar Izurieta Ferrer, quien fungió en el cargo entre el 10 de Marzo de 2006 y el 9 de Marzo de 2010.

${ }^{3}$ Utilizo los términos nación, identidad e identidad nacional bajo borradura. Pensar las categorías bajo borradura implica reconocer que aún después de haber criticado y desestabilizado los conceptos, no podemos sino seguir dialogando desde ellos. La ganancia de su desconstrucción es que desesencializa los conceptos y así se muestra su contingencia.

${ }^{4}$ Por ejemplo, es un paso inicial y necesario para el análisis estructural del discurso (AED) (ver sección 3).

${ }^{5}$ Siguiendo una práctica común de los análisis de texto, se han numerado las líneas de párrafos citados para indicar al lector las secciones referidas en el análisis.

${ }^{6}$ La historiografía tradicional chilena (Barros 1999, de la que Bravo (1989) es un representante actual) ha creado un cierto mito de la figura de Diego Portales Palazuelos (1793-1837, Ministro de Estado de diferentes dependencias entre 1830 y 1837) y su idea de autoridad. Esta historiografía lo ha descrito como una de las figuras fundamentales de la organización política del Chile republicano. El ideal portaliano alude a un tipo de autoridad fuerte pero a la vez impersonal y justa. Cierta historiografía revisionista más reciente ha presentado a Portales como un personaje controvertido (su mejor ejemplo es Villalobos 2005).

${ }^{7}$ Es posible pensar en las categorías de contenidos manifiestos y contenidos latentes del análisis de los sueños de Freud.

${ }^{8}$ Me he permitido adaptar con libertad sólo algunas ideas de Freeden (1996). Desde luego, varias diferencias son notorias, como la que se refiere a la preferencia de Freeden por el concepto de ideología en lugar de discurso, que es la mía. En segundo lugar, para producir una explicación gráfica utilizo elementos básicos de la teoría de conjuntos, cosa que Freeden no realiza.

${ }^{9}$ Investidura es un concepto psicoanalítico que remite a la simbolización cargada de energía libidinal y afectos de ciertos significantes privilegiados por el discurso.

10 http://www.ejercito.cl/nuestro_ejercito/discursos.php?PHPSESSID=04d92e 5a39ac6d349a71146af22e787d (26/05/2008). Discurso del Generla Cheyre pronunciado el 7-12-2004.

[11 http://www.memoriachilena.cl/temas/documento_detalle2.asp?id=MC000764, discurso del 11-03-81 (15-04-2010). 
Polis, Revista Latinoamericana, Volumen 13, $N^{\circ}$ 38, 2014

12 http://www.ejercito.cl/nuestro_ejercito/mision.php (26/05/2008).

${ }^{13}$ Es interesante notar que en lengua alemana la palabra Ausgrenzung es una alternativa a Exklusion (exclusión). Ausgrenzung contiene la raíz Grenze (frontera) a la que se le antepone el prefijo aus - que quiere decir afuera o fuera. 


\section{Bibliografía}

Anderson, Benedict (1993), Imagined Communities. Reflections on the Origin and Spread of Nationalism. Verso, Londres.

Barros, Diego (1999), Historia General de Chile, varios tomos. Editorial Universitaria, Santiago de Chile.

Bravo, Bernardino (comp.) (1989), Portales, el Hombre y su Obra. La Consolidación del Gobierno Civil, Editorial Andrés Bello, Santiago de Chile.

Butler, Judith (1990), Gender Trouble, Routledge, Londres.

Idem (1993), Bodies that Matter, Routledge, Londres.

Cheyre, Juan Emilio, Exposición del 20 de Noviembre de 2003 sobre Cohesión social y la Globalización.

Coffey, Amanda y Paul Atkinson (1996), Making Sense of Qualitative Data: Complementary Research Strategies, Sage, Londres.

Ejército de Chile Nuestra Misión, http://www.ejercito.cl/nuestro_ejercito/ mision.php (26/05/2008).

Freeden, Michael (1996), Ideologies and Political Theory: A Conceptual Approach, OUP, Oxford.

Gissi, Jorge (2000), “Identidad Nacional Chilena: Nuestro Perfil Psicosocial”. En VVAA ¿Hay Patria que defender?: la Identidad Nacional Frente a la Globalización, CED Ediciones del Segundo Centenario, Santiago de Chile.

Góngora, Mario (1988), Ensayo histórico sobre la noción de estado en Chile en los siglos XIX y XX, $2^{\mathrm{a}}$ ed., Editorial Universitaria, Santiago de Chile.

Hall, Stuart (2003), “Introducción: ¿Quién necesita “Identidad”?”, en Cuestiones de Identidad Cultural, S. Hall \& P. Du Gay (eds.), Amorrortu, Buenos Aires: 13-39.

Hobsbawm, Eric (2000), Naciones y nacionalismo desde 1780, Crítica, Barcelona.

Izurieta, Óscar (2007), Discurso con motivo del Juramento a la Bandera del 10 de Julio de 2007.

Laclau, Ernesto (1990), New Reflections on the Revolution of Our Time, Verso, Londres.

Laclau, Ernesto y Lilian Zac (1994), “Minding the Gap” en The Making of Political Identities, E. Laclau y L. Zac (eds.), Verso, Londres: 11-39. 
Larraín, Jorge (1996), Modernidad, Razón e Identidad en América Latina, Editorial Andrés Bello, Santiago de Chile.

Idem (2000), “Elementos Teóricos para el Análisis de la Identidad Nacional y la Globalización”, en ¿Hay Patria que defender?: la Identidad Nacional frente a la Globalización, Varios Autores, CED, Ediciones del Segundo Centenario, Santiago de Chile: 73-96.

Idem (2001), Identidad Chilena, LOM Ediciones, Santiago de Chile.

Martinic, Sergio (1992), Análisis estructural, Cide, Santiago de Chile.

Idem (2006), "El estudio de las representaciones y el Análisis Estructural de Discurso”. En Metodologías de investigación social, M. Canales Cerón (Comp.), LOM Ediciones, Santiago: 299-319.

Subercaseaux, Bernardo (1999), “Caminos Interferidos: de lo Político a lo Cultural. Reflexiones sobre la Identidad Nacional”, Revista de Estudios Públicos (73) : 149-164.

Pinochet, Augusto (1974) Discurso del 11 de Marzo de 1974, http:// www.archivochile.com/Dictadura_militar/doc_jm_gob_pino8/ DMdocjm0005.pdf (24/052008).

Idem (1977), http://www.fundacionpinochet.cl/historia/chacarillas.html (1504-2010)

Idem (1981) del 11 de marzo de 1981, http://www.fundacionpinochet.cl/ historia/chacarillas.html (15-04-2010)

PNUD (2002), Desarrollo Humano en Chile. Nosotros los Chilenos: Un Desafío Cultural. Programa de Naciones Unidas Para el Desarrollo (PNUD), Santiago de Chile.

Villalobos, Sergio (2005), Portales, una falsificación histórica, Editorial Universitaria, Santiago de Chile.

•i•ek, Savoj (1989), The Sublime Object Of Ideology, Verso, Londres.

Idem (1994), “The Vicisitudes of Identity”, en The Making of Political Identities, E. Laclau y L. Zac (eds.), Verso, Londres: 40-75. 